\title{
Crystal structures of copper(I) and silver(I) chloride complexes containing 4-phenylthiosemicarbazide and triphenylphosphine ligands
}

\author{
Yupa Wattanakanjana ${ }^{\mathrm{a}, *}$, Kamonwan Janwatthana ${ }^{\mathrm{a}}$, Tanaporn Romyen ${ }^{\mathrm{a}}$, \\ Arunpatcha Nimthong-Roldán ${ }^{\mathrm{b}}$ \\ a Division of Physical Science, Faculty of Science, Prince of Songkla University, Songkhla 90112 Thailand \\ b Pre-Development Sciences, 211, 2nd Ave, Waltham, Massachusetts 02451 USA
}

*Corresponding author, e-mail: yupa.t@psu.ac.th

Received 11 Nov 2020

Accepted 23 Feb 2021

\begin{abstract}
Copper(I) and silver(I) chloride complexes containing triphenylphosphine $\left(\mathrm{PPh}_{3}\right)$ and 4-phenylthiosemicarbazide (4-PTSC) ligands were prepared and structurally analyzed, namely [CuCl(4-PTSC) $\left.\left(\mathrm{PPh}_{3}\right)_{2}\right](1)$ and [AgCl(4-PTSC) $\left.\left(\mathrm{PPh}_{3}\right)_{2}\right] \mathrm{CH}_{3} \mathrm{CN}$ (2). Both compounds (1) and (2) exhibit a distorted tetrahedral metal coordination environment with two $\mathrm{P}$ atoms from two $\mathrm{PPh}_{3}$ ligands, one terminal $\mathrm{S}$ atom from the 4-PTSC ligand and a chloride ion. Intramolecular $\mathrm{N}-\mathrm{H} \cdots \mathrm{Cl}$ and $\mathrm{N}-\mathrm{H} \cdots \mathrm{N}$ hydrogen bonds are observed (graph set motifs $\mathrm{S}(6)$ and $\mathrm{S}(5)$ ), respectively). In the crystals of both complexes, molecules are linked to form dimers via bifurcated $\mathrm{N}-\mathrm{H} \cdots \mathrm{Cl}$ hydrogen bonds involving the amine and chloride units. For compound (2), a solvate acetonitrile molecule acts as a hydrogen bond donor and acceptor via $\mathrm{C}-\mathrm{H}\left(\mathrm{CH}_{3} \mathrm{CN}\right) \cdots \mathrm{Cl}$ and $\mathrm{C}-\mathrm{H} \cdots \mathrm{N}\left(\mathrm{CH}_{3} \mathrm{CN}\right)$ interactions, leading to the formation of 1D chains along [010].
\end{abstract}

KEYWORDS: silver(I) chloride, copper(I) chloride, 4-phenylthiosemicarbazide, crystal structure, intra- and intermolecular hydrogen bonding

\section{INTRODUCTION}

Thiosemicarbazide and thiosemicarbazide derivatives have for several decades attracted attention due to a range of biological activities that they possess such as anticancer, antimicrobial, antifungal $[1,2]$, anticonvulsant, antimalarial, analgesic, and antiinflammatory properties [3-6]. Therefore, many scientists have prepared members of these compounds as target structures to estimate and evaluate their biological activities. Thiosemicarbazides may also act as ligands in metal complexes, featuring both soft sulfur and hard nitrogen donor atoms as potential sites for coordination that give them an affinity for chelation to divalent metal ions such as $\mathrm{Fe}^{2+}, \mathrm{Zn}^{2+}, \mathrm{Cu}^{2+}$, and $\mathrm{Mn}^{2+}$ $[7,8]$. Many of the thiosemicarbazide's biological and pharmaceutical activities are generally assumed to originate from these metal-complexing properties and their capacity to act as in vivo reducing agents. Thiosemicarbazide and their metal complexes have thus been extensively investigated, e.g. for their antiviral properties [9], or for their anticancer activities $[10,11]$. Most notable here is 3-aminopyridine-2-carboxaldehyde (3-AP or Triapine () , which is currently tested in a randomized phase III trial as an addition to the usual chemotherapy treatment (Cisplatin) during radiation therapy for advanced-stage cervical and vaginal cancers $[12,13]$. Several copper(I) and silver(I) complexes of thiosemicarbazide derivatives have been prepared and characterized, and an unusual enhancement in antitubercular activity has been observed for some of these complexes [14]. We recently reported a series of metal thiourea complexes prepared by reacting copper(I) or silver(I) halide with triphenylphosphane and 1-(4-nitrophenyl)thiourea, NPTU [15-17]; we report herein the synthesis and crystal structures of copper(I) and silver(I) chloride complexes containing triphenylphosphine $\left(\mathrm{PPh}_{3}\right)$ and 4-phenylthiosemicarbazide (4-PTSC) ligands (Fig. 1).

\section{MATERIALS AND METHODS}

\section{Materials}

The reagents and solvents used in the synthesis were obtained from commercial suppliers and used directly without further purification. Copper(I) chloride, silver(I) chloride, triphenylphosphine, and 4-phenylthiosemicarbazide were purchased from Sigma Aldrich (USA). Infrared spectra were mea- 


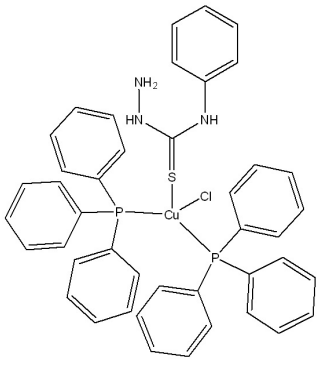

(1)

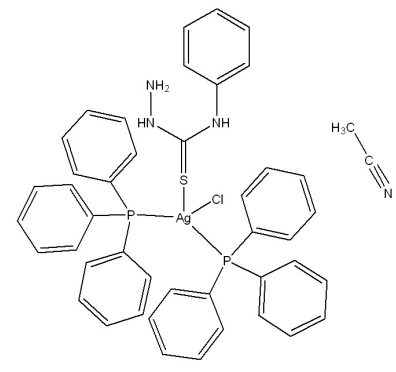

(2)
Fig. 1 Chemical structures of $\left[\mathrm{CuCl}(4-\mathrm{PTSC})\left(\mathrm{PPh}_{3}\right)_{2}\right]$ (1) and $\left[\mathrm{AgCl}(4-\mathrm{PTSC})\left(\mathrm{PPh}_{3}\right)_{2}\right] \mathrm{CH}_{3} \mathrm{CN}(2)$.

sured in the region of $4000-400 \mathrm{~cm}^{-1}$ on a PerkinElmer Infrared Spectrophotometer (Spectrum BX, England) using potassium bromide pellets.

\section{Synthesis of [CuCl(4-PTSC) $\left.\left(\mathrm{PPh}_{3}\right)_{2}\right]$ (1)}

Triphenylphosphane, $\mathrm{PPh}_{3}(0.16 \mathrm{~g}, 0.61 \mathrm{mmol})$, was dissolved in $30 \mathrm{ml}$ of acetonitrile at $339.15 \mathrm{~K}$, and copper(I) chloride, $\mathrm{CuCl}(0.03 \mathrm{~g}, 0.30 \mathrm{mmol})$, was added. The mixture was stirred for $3 \mathrm{~h}$, and then 4-phenylthiosemicarbazide, 4-PTSC (0.05 g, $0.30 \mathrm{mmol}$ ), was added. The resulting reaction mixture was heated under reflux for $7 \mathrm{~h}$ during which the precipitate gradually disappeared. The resulting clear solution was filtered and left to evaporate for several days at room temperature, leaving a crystalline complex, which was filtered off and dried in vacuo (0.10 g, 42\% yield). M.p. 171-172 K. IR bands $\left(\mathrm{KBr}, \mathrm{cm}^{-1}\right)$ : $3168.07(\mathrm{w})$, 1964.93(w), 1888.21(w), 1820.27(w), 1629.43(w), 1594.52(w), 1503.44(w), 1289.86(m), 1090.41(w), 1024.65(w), 897.53(m), 851.50(w), 700.95(s), 509.56(s).

\section{Synthesis of $\left[\mathrm{AgCl}(4-\mathrm{PTSC})\left(\mathrm{PPh}_{3}\right)_{2}\right] \mathrm{CH}_{3} \mathrm{CN}$ (2)}

Triphenylphosphine, $\mathrm{PPh}_{3}(0.16 \mathrm{~g}, 0.61 \mathrm{mmol})$, was dissolved in $30 \mathrm{ml}$ of acetonitrile at $340 \mathrm{~K}$, and silver(I) chloride, $\mathrm{AgCl}$ (0.04 g, $0.299 \mathrm{mmol}$ ), was added. The mixture was stirred for $4 \mathrm{~h}$, and then 4-phenylthiosemicabazide, 4-PTSC $(0.05 \mathrm{~g}$, $0.299 \mathrm{mmol}$ ), was added. The resulting reaction mixture was heated under reflux for $7 \mathrm{~h}$ during which the precipitate gradually disappeared. The resulting clear solution was filtered and left to evaporate at room temperature. The crystalline complex, which was deposited upon standing for a couple of days, was filtered off and dried in vacuo $(0.16 \mathrm{~g}, 66 \%$ yield $)$. M.p. 450-452 K. IR bands $\left(\mathrm{KBr}, \mathrm{cm}^{-1}\right)$ : 3311(w), 3263(w), 3148(w), 1961(w), 1625(w), 1599(w), 1544(w), 1432(w), 1282(w), 1209(w), 1094(w), 1026(w), 996(w), 968(w), 907(w), 852(w), 741(m), 686(w), 489(s), 450(w), 437(w).

\section{X-ray crystallographic analysis}

X-ray diffraction data for (1) and (2) were obtained on a Bruker Quest diffractometer (D8 Quest, Germany) with Mo- $K_{\alpha}$ radiation $(\lambda=0.71073 \AA)$ at $150 \mathrm{~K}$. Data were collected, and reflections were indexed and processed using APEX3 [18]. Space groups were assigned, and structures were solved by direct methods using XPREP within the SHELXTL suite of programs $[19,20]$ and refined using Shelxl [21] and Shelxle [22]. Crystallographic data are given in Table 1. Refinements for (1): crystal data, data collection, and structure refinement details are summarized in Table 1 . All $\mathrm{H}$ atoms attached to carbon atoms were positioned geometrically and constrained to ride on their parent atoms with $\mathrm{C}-\mathrm{H}=0.95 \AA$. The nitrogen bound $\mathrm{H}$ atoms were located in difference-Fourier maps and were refined with an $\mathrm{N}-\mathrm{H}=0.831$ (19)$0.89(2) \AA . U_{\text {iso }}(\mathrm{H})$ values were set to $1.2 U_{\text {eq }}(\mathrm{C} / \mathrm{N})$. Refinements for (2): crystal data, data collection, and structure refinement details are summarized in Table 1. All $\mathrm{H}$ atoms attached to carbon atoms were positioned geometrically and constrained to ride on their parent atoms with $\mathrm{C}-\mathrm{H}=0.95 \AA$. The nitrogen bound $\mathrm{H}$ atoms were located in differenceFourier maps and were refined with an $\mathrm{N}-\mathrm{H}=$ 0.858 (19) -0.892 (19) $\AA$. $U_{\text {iso }}(\mathrm{H})$ values were set to $1.2 U_{\mathrm{eq}}(\mathrm{C} / \mathrm{N})$. Reflections $-112,210,-211$, and 204 were affected by the beam stop and were omitted from the refinement. CCDC 2042521 for (1) and 2042520 for (2) contain the supplementary crystallographic data for this paper. These data can be obtained free of charge from The Cambridge Crystallographic Data Center (https://www.ccdc. cam.ac.uk).

\section{RESULTS AND DISCUSSION}

The reaction of copper(I) chloride with 4-phenylthiosemicarbazide (4-PTSC) and triphenylphosphine $\left(\mathrm{PPh}_{3}\right)$ ligands in 1:1:2 ratio in acetonitrile yielded the copper complex [CuCl(4-PTSC) $\left.\left(\mathrm{PPh}_{3}\right)_{2}\right]$ (1) in a triclinic setting in space group $P \overline{1}$. The analogous reaction with silver(I) chloride yielded the silver complex [AgCl(4-PTSC) $\left.\left(\mathrm{PPh}_{3}\right)_{2}\right]$, which crystallized as the mono-acetonitrile solvate $[\mathrm{AgCl}(4-$ PTSC) $\left.\left(\mathrm{PPh}_{3}\right)_{2}\right] \mathrm{CH}_{3} \mathrm{CN}$ (2) in space group $P 2_{1} / c$. Soft sulfur donor atom from the thiosemicarbazide 
Table 1 Crystal data and structure refinement details for (1) and (2).

\begin{tabular}{|c|c|c|}
\hline & {$\left[\mathrm{CuCl}(4-\mathrm{PTSC})\left(\mathrm{PPh}_{3}\right)_{2}\right](1)$} & {$\left[\mathrm{AgCl}(4-\mathrm{PTSC})\left(\mathrm{PPh}_{3}\right)_{2}\right] \mathrm{CH}_{3} \mathrm{CN}(2)$} \\
\hline \multicolumn{3}{|l|}{ Crystal data } \\
\hline Chemical formula & $\mathrm{C}_{43} \mathrm{H}_{39} \mathrm{ClCuN}_{3} \mathrm{P}_{2} \mathrm{~S}$ & $\mathrm{C}_{43} \mathrm{H}_{39} \mathrm{AgClN}{ }_{3} \mathrm{P}_{2} \mathrm{~S} \cdot \mathrm{C}_{2} \mathrm{H}_{3} \mathrm{~N}$ \\
\hline$M r$ & 790.76 & 876.14 \\
\hline Crystal system, space group & Triclinic, $P \overline{1}$ & Monoclinic, $P 2_{1} / c$ \\
\hline Temperature $(\mathrm{K})$ & 150 & 150 \\
\hline$a, b, c(\AA)$ & $10.1234(4), 13.2260(6), 16.4011(7)$ & 16.5657 (7), $9.4156(4), 26.5967$ (11) \\
\hline$\alpha, \beta, \chi\left(^{\circ}\right)$ & $105.0998(16), 93.9536(16), 112.2322$ (15) & $90,95.4679(13), 90$ \\
\hline$V\left(\AA^{3}\right)$ & $1927.76(14)$ & $4129.6(3)$ \\
\hline$Z$ & 2 & 4 \\
\hline Radiation type & Mo $K \alpha$ & Mo $K \alpha$ \\
\hline$\mu\left(\mathrm{mm}^{-1}\right)$ & 1.81 & 0.72 \\
\hline Crystal size (mm) & $0.46 \times 0.32 \times 0.22$ & $0.56 \times 0.53 \times 0.33$ \\
\hline \multicolumn{3}{|l|}{ Data collection } \\
\hline Diffractometer & $\begin{array}{l}\text { Bruker AXS D8 Quest CMOS } \\
\text { diffractometer }\end{array}$ & $\begin{array}{l}\text { Bruker AXS D8 Quest CMOS } \\
\text { diffractometer }\end{array}$ \\
\hline Absorption correction & $\begin{array}{l}\text { Multi-scan SADABS 2016/2: Krause L, } \\
\text { Herbst-Irmer R, Sheldrick GM, Stalke D, } \\
\text { J Appl Cryst } 48 \text { (2015), 3-10 }\end{array}$ & $\begin{array}{l}\text { Multi-scan SADABS 2016/2: Krause, L., } \\
\text { Herbst-Irmer R, Sheldrick GM, Stalke D, } \\
\text { J Appl Cryst } 48 \text { (2015), 3-10 }\end{array}$ \\
\hline $\begin{array}{l}\text { No. of measured, } \\
\text { independent and } \\
\text { observed }[I>2 \sigma(I)] \\
\text { reflections }\end{array}$ & $93937,14713,11031$ & $54737,15053,12221$ \\
\hline$R$ int & 0.041 & 0.047 \\
\hline$(\sin \theta / \lambda) \max \left(\AA^{-1}\right)$ & 0.771 & 0.770 \\
\hline \multicolumn{3}{|l|}{ Refinement } \\
\hline$R[F 2>2 \sigma(F 2)], w R(F 2), S$ & $0.036,0.086,1.03$ & $0.028,0.074,1.05$ \\
\hline No. of reflections & 14713 & 15053 \\
\hline No. of parameters & 472 & 525 \\
\hline $\mathrm{H}$-atom treatment & $\begin{array}{l}\mathrm{H} \text { atoms treated by a } \\
\text { mixture of independent } \\
\text { and constrained refinement }\end{array}$ & $\begin{array}{l}\mathrm{H} \text { atoms treated by a mixture } \\
\text { of independent } \\
\text { and constrained refinement }\end{array}$ \\
\hline$\Delta \rho \max , \Delta \rho \min \left(\mathrm{e}^{-3}\right)$ & $0.60,-0.43$ & $0.63,-0.54$ \\
\hline
\end{tabular}

Computer programs: Apex3, SAINT [18], SHELXS9 [19], SHELXL2014/7 [20], SHELXLE Rev714 [21], Mercury [26], SHELXL97, and publCIF [27].

Table 2 Hydrogen-bond geometry $\left(\AA \stackrel{\circ}{\circ}^{\circ}\right)$ for $\left[\mathrm{CuCl}(4-\mathrm{PTSC})\left(\mathrm{PPh}_{3}\right)_{2}\right](1)$ and $\left[\mathrm{AgCl}(4-\mathrm{PTSC})\left(\mathrm{PPh}_{3}\right)_{2}\right] \mathrm{CH}_{3} \mathrm{CN}(2)$.

\begin{tabular}{lllll}
\hline $\mathrm{D}-\mathrm{H} \cdots \mathrm{A}$ & $\mathrm{D}-\mathrm{H}$ & $\mathrm{H} \cdots \mathrm{A}$ & $\mathrm{D} \cdots \mathrm{A}$ & $\mathrm{D}-\mathrm{H} \cdots \mathrm{A}$ \\
\hline Compound (1) & & & & \\
$\mathrm{N}_{1}-\mathrm{H}_{1} \cdots \mathrm{N}_{3}$ & $0.832(19)$ & $2.235(18)$ & $2.6500(18)$ & $111.1(15)$ \\
$\mathrm{N}_{2}-\mathrm{H}_{2} \cdots \mathrm{Cl}_{1}$ & $0.831(19)$ & $2.373(19)$ & $3.1751(12)$ & $162.5(17)$ \\
$\mathrm{N}_{3}-\mathrm{H}_{3} A \cdots \mathrm{Cl}_{1}^{\mathrm{i}}$ & $0.89(2)$ & $2.62(2)$ & $3.5046(14)$ & $173.5(16)$ \\
\hline Compound (2) & & & & 113 \\
$\mathrm{~N}_{1}-\mathrm{H}_{1} \cdots \mathrm{N}_{3} \mathrm{a}$ & 0.88 & 2.12 & $2.592(10)$ & 138 \\
$\mathrm{~N}_{1}-\mathrm{H}_{1} \cdots \mathrm{N}_{4}$ & 0.88 & 2.45 & $3.155(2)$ & $164(4)$ \\
$\mathrm{N}_{2} \mathrm{a}-\mathrm{H}_{2} \mathrm{a} \cdots \mathrm{Cl}_{1}$ & $0.88(2)$ & $2.34(2)$ & $3.200(11)$ & $168(5)$ \\
$\mathrm{N}_{2} B \mathrm{~b}-\mathrm{H}_{2} B \mathrm{~b} \cdots \mathrm{Cl}_{1}$ & $0.89(2)$ & $2.21(3)$ & $3.086(13)$ & $131(5)$ \\
$\mathrm{N}_{3} B \mathrm{~b}-\mathrm{H}_{3} \mathrm{Cb} \cdots \mathrm{Cl}_{1}^{\mathrm{i}}$ & $0.86(2)$ & $2.72(5)$ & $3.317(2)$ & 133 \\
$\mathrm{C} 33-\mathrm{H} 33 \cdots \mathrm{N}_{4}^{\mathrm{iii}}$ & 0.95 & 2.60 & $3.517(2)$ & 164 \\
$\mathrm{C} 45-\mathrm{H} 45 A \cdots \mathrm{Cl}_{1}^{\mathrm{ii}}$ & 0.98 & 2.57 & & \\
\hline
\end{tabular}

Symmetry codes: (i) $-x+1,-y,-z$; (ii) $-x+1,-y+2-z+1$; and (iii) $x,-y+3 / 2, z+1 / 2$. 


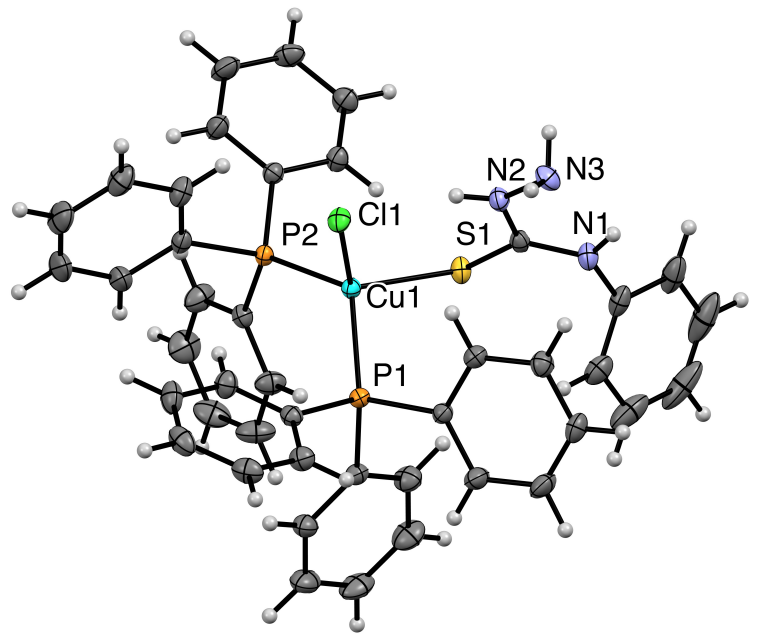

Fig. 2 Molecular structure of [CuCl(4-PTSC) $\left.\left(\mathrm{PPh}_{3}\right)_{2}\right]$ (1) with ellipsoid displacement drawn at the $50 \%$ probability level.

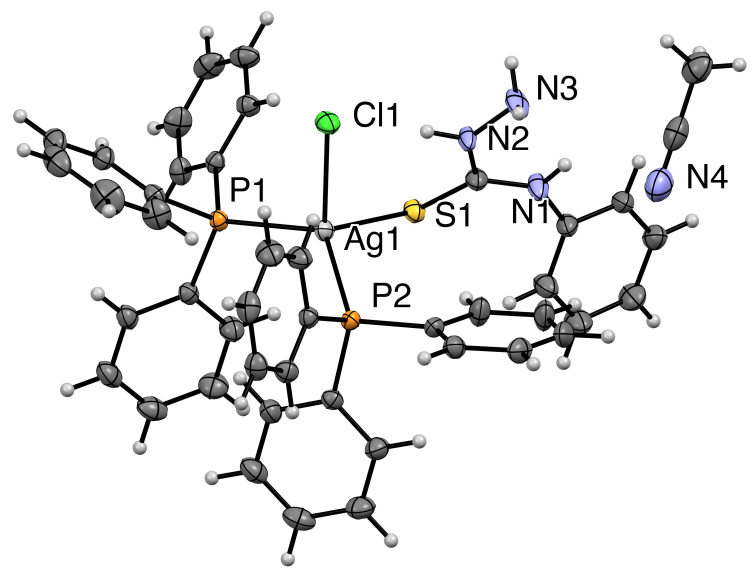

Fig. 3 Molecular structure of [AgCl(4-PTSC) $\left.\left(\mathrm{PPh}_{3}\right)_{2}\right]$ $\mathrm{CH}_{3} \mathrm{CN}$ (2) with ellipsoid displacement drawn at the $50 \%$ probability level. Disordered atoms were omitted for clarity.

is coordinated to both $\mathrm{Cu}$ and $\mathrm{Ag}$, and no interaction of the amine moiety with the metal is observed. Both complexes are monomeric and exhibit a distorted tetrahedral geometry in which the metal ion is coordinated to two $\mathrm{P}$ atoms from two $\mathrm{PPh}_{3}$ ligands, one terminal $\mathrm{S}$ atom from the 4-PTSC ligand and a chloride ion (Fig. 2 and Fig. 3). The monomeric structures are stabilized by an intramolecular $\mathrm{N}_{2}-\mathrm{H}_{2} \cdots \mathrm{Cl}_{1}$ hydrogen bond between the $\mathrm{NH}_{2}$ (4-PTSC) and the $\mathrm{Cl}$ atom and $\mathrm{N}_{1}-\mathrm{H}_{1} \cdots \mathrm{N}_{3}$ hydrogen bond between $\mathrm{NH}_{2}$ and $\mathrm{NH}$ of the thiosemicarbazide

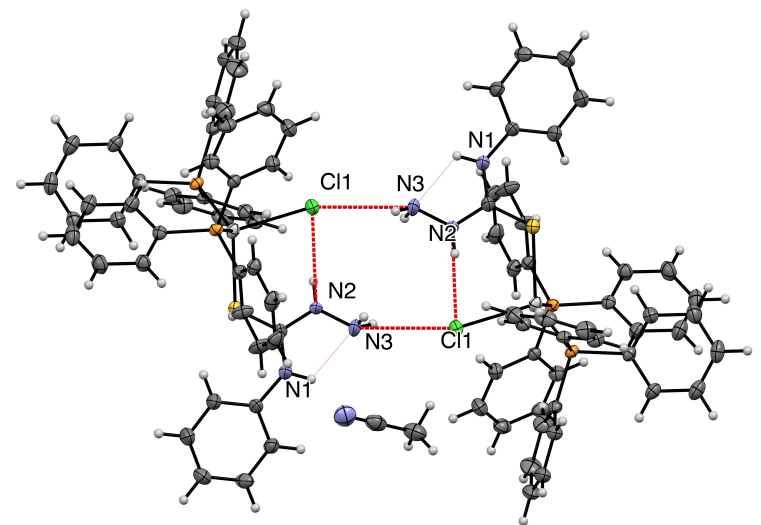

Fig. 4 Part of the crystal structure of [AgCl(4-PTSC) $\left.\left(\mathrm{PPh}_{3}\right)_{2}\right] \mathrm{CH}_{3} \mathrm{CN}(2)$, showing the dimer formed by intermolecular $\mathrm{N}-\mathrm{H} \cdots \mathrm{Cl}$ hydrogen bonds (shown as dashed lines).

moiety (graph set [23] motif $\mathrm{S}(6)$ and $\mathrm{S}(5)$, respectively) (Table 2). The $\mathrm{Cu}-\mathrm{S}$ distance in (1) of 2.3389 (4) $\AA$ is close to that of another related tetrahedral complex, [CuCl $\left(\eta 1-\mathrm{S}-\mathrm{H}_{2}\right.$ itsc $\left.)\left(\mathrm{Ph}_{3} \mathrm{P}\right)_{2}\right]$ $\left(\mathrm{H}_{2}\right.$ itsc $=$ isatin-3-thiosemicarbazone $)$ [24], but smaller than 2.3893 (5) $\AA$ in $[\mathrm{CuCl}(\eta 1$-S$\mathrm{H}$ Intsc $\left.)\left(\mathrm{Ph}_{3} \mathrm{P}\right)_{2}\right]$ [14]. The $\mathrm{Cu}-\mathrm{P}$ bond lengths of 2.2710 (4)-2.3109 (4) $\AA$ are a bit larger than the values of 2.2602 (4) -2.2671 (4) $\AA$ observed for [ $\mathrm{CuCl}\left(\mathrm{C}_{7} \mathrm{H}_{7} \mathrm{~N}_{3} \mathrm{O}_{2} \mathrm{~S}\right)\left(\mathrm{C}_{18} \mathrm{H}_{15} \mathrm{P}\right)_{2}$ ] [15]. In compound (2), the Ag-S bond length of 2.6108 (4) $\AA$ is similar to the bond length of 2.628 (8) $\AA$ found in [AgCl( $\eta 1-\mathrm{S}-\mathrm{H}$ Intsc $)\left(\mathrm{Ph}_{3} \mathrm{P}\right)_{2}$ ] [14]. The Ag-P bond lengths of 2.4703 (3) -2.4750 (4) $\AA$ are close to the values of 2.4409 (7)-2.4879 (7) $\AA$ for $\left[\mathrm{AgCl}\left(\eta^{1}\right.\right.$ $\mathrm{S}-\mathrm{H}$ pytsc) $\left.\left(\mathrm{PPh}_{3}\right)_{2}\right] \cdot \mathrm{CH}_{3} \mathrm{CN}$ [25]. In the crystals of (1) and (2), the amine $\mathrm{NH}_{2}$ moieties of 4-PTSC and $\mathrm{Cl}$ atom of neighboring molecules are linked through intermolecular $\mathrm{N}_{3}-\mathrm{H}_{3} \cdots \mathrm{Cl}_{1}$ hydrogen bonds, forming dimers (Fig. 4). For compound (2), the acetonitrile molecules are connected to dimers through $\mathrm{C}_{45}-\mathrm{H}_{45} \mathrm{~A}\left(\mathrm{CH}_{3} \mathrm{CN}\right) \cdots \mathrm{Cl}_{1}$ and $\mathrm{C}_{33}-\mathrm{H}_{33} \cdots \mathrm{N}_{4}\left(\mathrm{CH}_{3} \mathrm{CN}\right)$ hydrogen bonds, leading to the formation of 1D chains along [010] (Fig. 5, Table 2). The results from IR spectroscopy are corresponding to the X-ray crystallographic data; the characteristic peak of $v(\mathrm{C}=\mathrm{S})$ of both complexes appeared at lower energy than that of the stretching presented in the free 4-PTSC ligand $\left(896 \mathrm{~cm}^{-1}\right)$ supporting the coordination of the thione sulfur to a metal center. 


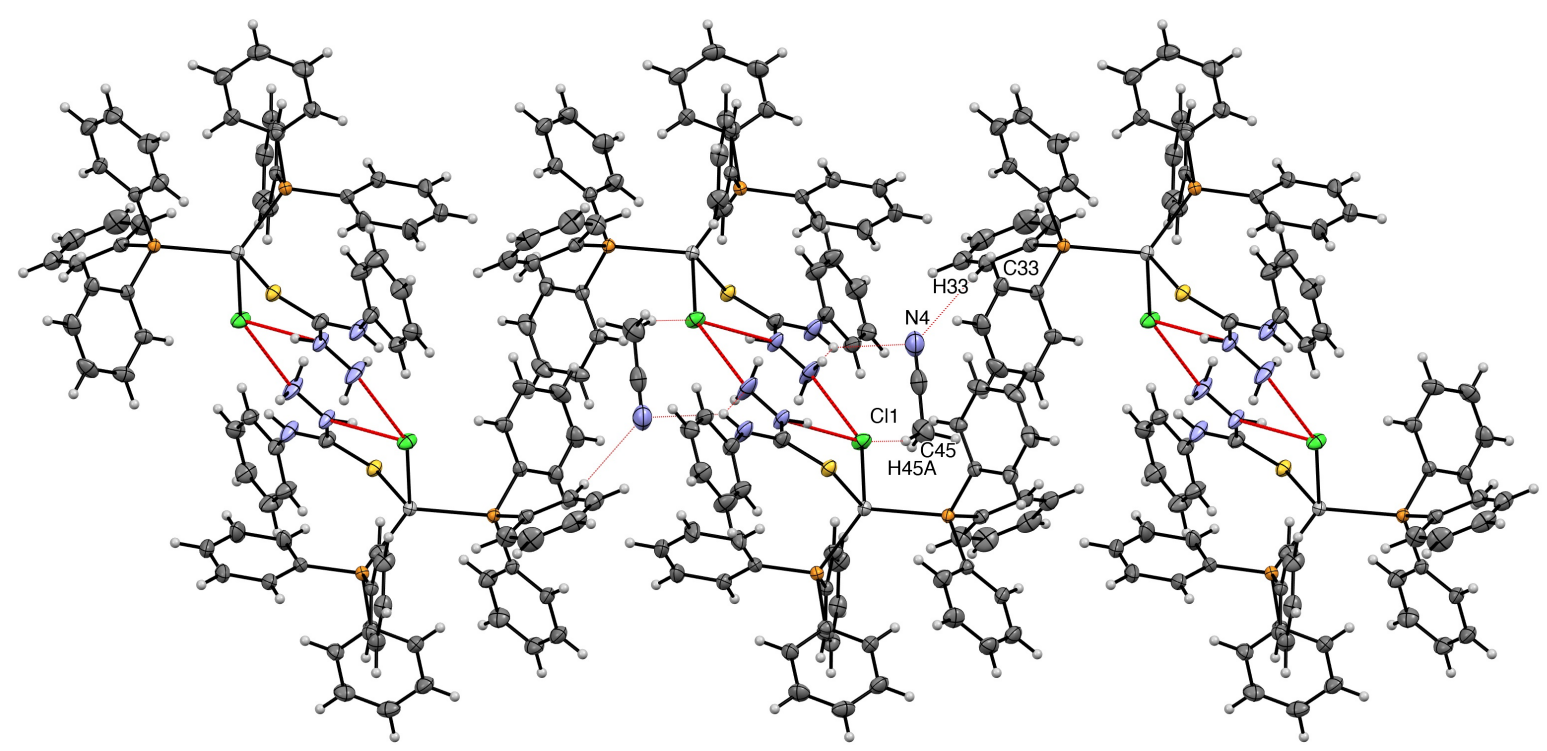

Fig. 5 Part of the crystal structure of $\left[\mathrm{AgCl}(4-\mathrm{PTSC})\left(\mathrm{PPh}_{3}\right)_{2}\right] \mathrm{CH}_{3} \mathrm{CN}(2)$, showing intermolecular $\mathrm{C}-\mathrm{H} \cdots \mathrm{N}$ and $\mathrm{C}-\mathrm{H} \cdots \mathrm{Cl}$ hydrogen bonds and forming long chains along $b$-axis (shown as dashed lines).

\section{CONCLUSION}

The complexes [CuCl(4-PTSC) $\left.\left(\mathrm{PPh}_{3}\right)_{2}\right]$ (1) and $\left[\mathrm{AgCl}(4-\mathrm{PTSC})\left(\mathrm{PPh}_{3}\right)_{2}\right] \mathrm{CH}_{3} \mathrm{CN}$ (2) were prepared from MCl:4-PTSC: $\mathrm{PPh}_{3}$ in 1:1:2 molar ratios in acetonitrile. The structures of the complexes were determined using single crystal X-ray diffraction analysis and further characterized by IR spectroscopy. Both complexes display a distorted tetrahedral coordination with two $\mathrm{PPh}_{3}$ ligands, one 4-PTSC ligand and a chloride ion. In the crystals, there are intraand intermolecular hydrogen bonds to connect complexes into dimers. The existence of a solvate acetonitrile in (2) plays an important role in connecting each dimer to form a one-dimensional network.

Acknowledgements: Financial support from the Division of Physical Science, Faculty of Science, Prince of Songkla University, is gratefully acknowledged. We would like to thank Dr. Matthias Zeller and Purdue University for assistance with the X-ray structure determination and use of equipment, funded by the National Science Foundation of the United States (CHE-1625543).

\section{REFERENCES}

1. Pishawikar SA, More HN (2017) Synthesis, docking and in-vitro screening of mannich bases of thiosemicarbazide for anti-fungal activity. Arab J Chem 10, S2714-S2722.

2. Zhang $\mathrm{Y}$, Wang $\mathrm{R}$, Zhang $\mathrm{T}$, Yan $\mathrm{W}$, Chen $\mathrm{Y}$, Zhang Y, Zhou M (2019) Benzofuran-isatinhydroxylimine/thiosemicarbazide hybrids: Design, synthesis and in vitro anti-mycobacterial activity evaluation. Chin Chem Lett 30, 653-655.

3. Metwally MA, Bondock S, El-Azap H, Kandeel EE (2011) Thiosemicarbazides: synthesis and reactions. J Sulfur Chem 32, 489-519.

4. Singhal S, Arora S, Agarwal S, Sharma R, Singhal $\mathrm{N}$ (2013) A review on potential biological activities of thiosemicarbazides. World J Pharm Pharm Sci 2, 4661-4681.

5. Bhat MA, Khan AA, Ghabbour HA, Quah CK, Fun HK (2016) X-ray structure and antimicrobial activity of N-(4-chlorophenyl)-2-(pyridin-4-ylcarbonyl) hydrazinecarbothioamide. Trop J Pharm Res 15, 1751-1757.

6. Rane RA, Naphade SS, Bangalore PK, Palkar MB, Shaikh MS, Karpoormath R (2014) Synthesis of novel 4-nitropyrrole-based semicarbazide and thiosemicarbazide hybrids with antimicrobial and anti-tubercular activity. Bioorg Med Chem Lett 24, 3079-3083.

7. Casas JS, Garcia-Tasende MS, Sordo J (2000) Main group metal complexes of semicarbazones and thiosemicarbazones. A structural review. Coord Chem Rev 209, 197-261.

8. Milunovic MNM, Enyedy ÉA, Nagy NV, Kiss T, Trondl R, Jakupec MA, Keppler BK, Krachler R, et al (2012) 1- and d-Proline thiosemicarbazone conjugates: Coordination behavior in solution and the effect of copper(II) coordination on their antiproliferative activity. Inorg Chem 51, 9309-9321.

9. Cihan-Üstündag G, Gürsoy E, Naesens L, UlusoyGüzeldemirci N, Çapan G (2016) Synthesis and antiviral properties of novel indole-based thiosemicar- 
bazides and 4-thiazolidinones. Bioorg Med Chem 24, 240-246.

10. Xie F, Cai H, Peng F (2018) Anti-prostate cancer activity of 8-hydroxyquinoline-2-carboxaldehydethiosemicarbazide copper complexes in vivo by bioluminescence imaging. J Biol Inorg Chem 23, 949-956.

11. Xie F, Peng F (2018) Anticancer activity of copper complex of (4R)-(-)-2-thioxo-4-thiazolidinecarboxylic acid and 3-rhodaninepropionic acid on prostate and breast cancer cells by fluorescent microscopic imaging. J Fluoresc 28, 89-96.

12. Kunos CA, Andrews SJ, Moore KN, Chon HS, Ivy SP (2019) Randomized phase II trial of triapinecisplatin-radiotherapy for locally advanced stage uterine cervix or vaginal cancers. Front Oncol 15, ID 1067.

13. Kunos CA, Ivy SP (2018) Triapine radiochemotherapy in advanced stage cervical cancer. Front Oncol 7, ID 149.

14. Khan A, Jasinski JP, Smolenski VA, Hotchkiss EP, Kelley PT, Shalit ZA, Kaur M, Paul K, et al (2018) Enhancement in anti-tubercular activity of indole based thiosemicarbazones on complexation with copper(I) and silver(I) halides: structure elucidation, evaluation and molecular modelling. Bioorg Chem 80, 303-318.

15. Nimthong-Roldán A, Promsuwhan N, Puetpaiboon W, Wattanakanjana Y, (2017) Crystal structure of chloridol[1-(4-nitrophenyl)thiourea- $\kappa S$ ]bis(triphenylphosphane-кP) copper(I). Acta Cryst E73, 41-44.

16. Nimthong-Roldán A, Sripa $P$, Wattanakanjana $Y$ (2017) Crystal structure of chlorido[1-(4-nitrophenyl)thiourea- $\kappa S$ ]bis (triphenylphosphane- $\kappa P$ )silver(I). Acta Cryst E73, 829-831.

17. Wattanakanjana Y, Puetpaiboon W, Sripa P, Nimthong-Roldán A (2020) Crystal structure of metal (I) bromide complexes containing 1-(4-nitro- phenyl)thiourea and triphenylphosphine ligands. ScienceAsia 46S, 74-78.

18. APEX3 v2016.9-0, Saint V8.34A, Saint V8.37A; 2016.

19. SHELXTL suite of programs, version 6.14; 2000-2003.

20. Sheldrick GM (2008) A short history of SHELX. Acta Cryst A64, 112-122.

21. Sheldrick GM (2015) Crystal structure refinement with SHELXL. Acta Crystallogr C 71, 3-8.

22. Hübschle CB, Sheldrick GM, Dittrich BJ (2011) ShelXle: a Qt graphical user interface for SHELXL. Appl Cryst 44, 1281-1284.

23. Etter MC, MacDonald JC, Bernstein J (1990) Graphset analysis of hydrogen-bond patterns in organic crystals. Acta Cryst B46, 256-262.

24. Lobana TS, Rekha, Pannu APS, Hundal G, Butcher RJ, Castineiras A (2017) Synthesis and structures of monomeric [chloro(isatin-3-thiosemicarbazone) bis(triphenyl-phosphine)]copper(I) and dimeric [dichlorobis(thiophene-2-carbaldehyde thiosemicarbazone)bis(triphenylphosphine)] dicopper(I)] complexes. Polyhedron 26, 2621-2628.

25. Lobana TS, Khanna S, Sharma R, Hundal G, Sultana R, Chaudhary M, Butcher R J, Castineiras A (2008) Versatility of thiosemicarbazones in the construction of monomers, dimers and hydrogen-bonded networks of silver(I) complexes. Cryst Growth Des 8, 1202-1212.

26. Macrae CF, Bruno IJ, Chisholm JA, Edgington PR, McCabe P, Pidcock E, Rodriguez-Monge L, Taylor R, et al (2008) Mercury CSD 2.0 - new features for the visualization and investigation of crystal structures. Appl Cryst 41, 466-470.

27. Westrip SPJ (2010) publCIF: software for editing, validating and formatting crystallographic information files. Appl Cryst 43, 920-925. 